\title{
African spirituality in the Johane Masowe Chishanu religious movement in Zimbabwe: A Christian church-sect dichotomy
}

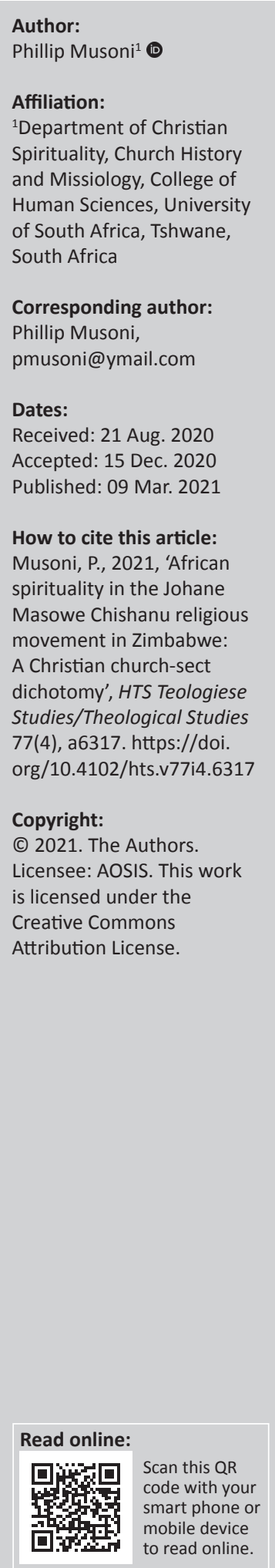

This study explored the impact of African indigenous spirituality on African indigenous churches (AICs), particularly in the Zimbabwean context, a special focus was on the Johane Masowe Chishanu (JMC) religious movement spirituality. The spirituality of the JMC religious movement is examined by cross-examining its denigration of the centrality of the Bible, the historical Jesus and the temple gathering as the movement appropriates and re-socialises traditional African shrines for religious gatherings. Thus, the following questions are raised in this study: is the appropriation and resocialisation of African traditional shrines, the denigration of the Bible and the disregarding of the historical Jesus for salvation by the JMC a conscious or unconscious move? If it is a conscious move, the follow-up question is: what motivates the JMC religious movement to regard such religious shrines, whilst disregarding the Bible and Jesus for its spirituality and, because of this, does the JMC religious movement retain the label 'a Christian church' or has become a sect?

Contribution: While majority of African scholars were celebrating the proliferation of Christianity in the continent as evidenced by an unremitting mushrooming of African Indigenous Churches, some Zimbabwean scholars were categorizing Johane Masowe Chishanu church a sect. Therefore, this article examine the veracity and provenances of the Johane Masowe Chishanu church-sect dichotomy in Zimbabwe.

Keywords: AICs; AIS; appropriation; shrines; reinterpretation; resocialisation.

\section{Introduction}

African indigenous churches (AICs) have received scholarly attention in recent years because of their unremitting mushrooming, particularly in Africa. Some of these AICs have also set up branches in Europe and America (Adogame 2013). This dramatic expansion of AICs in the 20th century, which has been referred to as 'the fourth great age of Christian expansion', has shifted the core of Christianity from Europe and America to Africa (Viera 2007:78). African indigenous churches are Christian churches founded by Africans in Africa and not by Western missionaries (Chitando 2004). The abbreviation 'AICs' is used by different scholars in different ways such as African Indigenous Churches (Turner 1967), African independent churches (Daneel 1987), African initiated churches (Hastings 1996), African instituted churches (Chitando 2004) and, of late, African international churches (Adogame 2013). By the end of the 20th century, AICs had spread across Africa, becoming the largest grouping of Christian churches on the continent (Kealotswe 2014:55). However, whilst some are celebrating the proliferation of Christianity in Africa, other scholars have categorised other AICs as non-Christian, thereby labelling them sects. For instance, in the Zimbabwean religious landscape, the Johane Masowe Chishanu (JMC) Churches (white garment churches [Vapositori]) are mostly categorised as sects by most scholars in the field of Theology and Religious studies. Examples of scholars who have categorised the white garment religious groups in Zimbabwe as sects include Machingura (2014), Sibanda (2017) and Guri (2018). However, whilst it is easy to categorise these religious movements as sects, the author argues in this new research study that such a conclusion needs to be revised. The reason for this submission is that it seems that there is no universally agreed-upon definition of what constitutes 'a church' in different disciplines, including theology.

Cognisant of these challenges, this article presents the trajectory of the emergence of a theological debate on the church-sect dichotomy. The selected central salient features that distinguish a Christian church from other religions discussed in this article include the use of the Bible for theology, the mediatorship of the historical Jesus for human salvation and temple gatherings 
associated with breaking of bread (eucharist). These were discussed because scholars who dismissed JMC as a sect measured the movement against these elements.

\section{Methodology}

The old debate on whether AICs are Christian churches continues to resurface. This debate was started by western scholars such as Sundkler (1961), Oosthuizen (1968) and Daneel (1973). These scholars used certain criteria to categorise AICs as non-Christian, which included withdrawal tendencies (Sundkler 1961), messianic tendencies (Dillon Malone 1978) and lack of a written scripture .... (Engelke 2005). The Zimbabwean scholars have also used the same criteria used by western scholars to categorise the JMC religious movement as a sect. However, the question raised in this article is: how valid is the criteria, and '[o]n top of which mountain does one stand to judge religion?' (Chitando, Mapuranga \& Taringa 2014). Alternatively, what method the Zimbabwean scholars have used to categorise the JMC religious movements as sects? Accordingly, this study employs descriptive and interpretive phenomenology in revisiting the Zimbabwean discourse on the 'church-sect dichotomy'.

The phenomenological approach, particularly in the study of religion, deals with the personal participation of a scholar in the religion he seeks to study in order to understand he essence (meaning) and manifestations of the religious phenomena of that particular religion (Keke 2010:16). Chitando and others argue that the literal meaning of phenomenology is the study of phenomena or appearance of things, specifically things, as they appear in the human experience (Chitando et al. 2014:117). Accordingly, one of the goals of a phenomenologist is to allow each religion to speak for itself and temporarily suspend issues pertaining to external validity (Chitando et al. 2014:121). The descriptive phenomenological approach, therefore, allows the phenomena to be discovered by the researcher by immersing himself or herself in the studied religion and by describing the data as accurately as possible, and by paying careful attention to various aspects to avoid premature interpretations (Cox 1992:32). In the course of this study, participant observations and interviews were used as tools to collect data. The interviews were guided using a semi-structured interview schedule that comprised of open-ended questions. The use of openended questions allowed for flexibility and further probing of the responses that the participants gave (Dube, Nkomo \& Khosa 2017:10). In order to avoid harm, informed consent, voluntary participation, confidentiality and anonymity were some of the ethical practices that were adhered to in this study.

The research methodology is, however, not only about collecting data. According to Gunda, there are essentially two issues concerning the methodology (Gunda 2014:146). The first relates to how one collects the data, and the second concerns how one interprets the data collected (Gunda 2014:146). Accordingly, an interpretive phenomenological analysis (IPA) was used to interpret the data collected. According to Denzin and Lincoln (eds. 2011:23), an IPA aims at understanding the life experiences of individuals and their beliefs without judging them. Thus, in accordance with the descriptive phenomenology and the IPA, the researcher first discussed how the JMC socialised both the selected Christian spiritual elements of faith and traditional African shrines and beliefs to inform the religious spirituality of the movement. After discussing the appropriation of the selected Christian spiritual elements of faith and African traditional shrines and beliefs, this study provides the JMC's interpretation of such elements. It is the author's view that the JMC's interpretation of the selected Christian spiritual elements of faith and its appropriation of some African traditional shrines for services and rituals will indicate whether the JMC religious movement is a Christian church or has become a sect.

\section{A church-sect dichotomy}

The discourse on the church-sect dichotomy was first introduced by a sociologist, Max Weber, in 1958. Weber developed the church-sect theory using a sociological lens; that is, he deliberated on how to distinguish a church from a sect in a given society (Johnson 1963:11). Thus, for him, a church is always supportive of the government, whilst a sect consists of people who are discontented with the government and, therefore, the members of a sect are always discouraged from participating in government affairs (Johnson 1963:12). It is against this background that, according to Weber, Islam is a church in an Islamic nation, whilst a Christian church is regarded as a sect in an Islamic nation. However, in terms of a sociological lens, a church can be a sect, whilst a sect can be a church depending on the society in which the religion is located. Accordingly, Weber's definition of a church has certain limitations. The challenge with this definition as stated above is that any movement can be a sect or a church depending on its location.

From a theological perspective, the debate on the churchsect dichotomy can be backdated to the time of the patristic fathers. Many councils were set up to address a number of theological disputes and amongst those was the church-sect dichotomy. As noted by Burridge (2001:55), the centrality of the Bible with regards to theology, the proclamation of the historical Jesus as the Messiah, the central teachings of Jesus, the centrality of the doctrine of Jesus' death, and his resurrection and the temple gathering associated with the breaking of bread were the key spiritual elements of faith that seemed to distinguish a Christian church from a non-Christian movement. Thus, according to the abovementioned criteria, an authentic Christian church entails a group of people who believe the biblical story of Jesus Christ's birth, death, burial and resurrection for the salvation of humankind (Burridge 2001:13). In addition, Holt (2005:13) argued that any religious group that does not regard the 
centrality of the Bible and the belief on Jesus Christ as normative for its spirituality is a non-Christian group. In support, Mbiti raised that the chief yardstick that is used to unify Christian denominations is their emphasis on the centrality of the Bible with regards to theology (Mbiti 1986:19). Mbiti further opined that for those claiming to be Christians, nothing can substitute the Bible. Furthermore, Mushete argued that the era of individualism marked by closed boundaries is over, and hence, the concept of 'universalisation' (Mushete 1978:53). However, this universalisation is not uniformisation. As stated by Mushete, there will always be a space in this cultural unification for a certain degree of diversity. In denominational diversity, which is the result of cultural diversity, Christian churches are united by their continuous emphasis on the centrality of the temple gathering associated with the breaking of bread in commemoration of the death and resurrection of Jesus Christ (Mushete 1978). Accordingly, based on the negation of the aforementioned spiritual elements of faith, critics of the JMC categorised the movement as a sect.

\section{Withdrawal tendencies}

The first characteristic that distinguishes the JMC from Christian churches, as identified by scholars, pertains to their withdrawal tendencies. These tendencies are described as actions where a group of people decide to withdraw from certain key practices of a mother religion from which the group split during the process of rebranding its theology (Mackay \& Motsi 1988:19). Historically, early scholars argued that AICs, in general, emerged as withdrawal movements because of the racial hostility experienced by blacks with regard to the white administrators. Turner (1967) and Barrett (1968) and Sundkler (1991). argued that AICs were established in reaction to colonial oppression and missionary paternalism. Thus, according to Mukonyora, the JMC chose to withdraw from congregating in church buildings in order to distance itself from the missionary colonial way of worshipping (in buildings) (Mukonyora 2007:17).

This withdrawal occurred with the aim of expressing discontentment with colonial Christianity and of expressing a desire to revive the old-world order (Machingura 2014:178). Thus, in the JMC religious movement, congregating in open spaces signifies the withdrawal from congregating in buildings, a practice introduced by missionaries, as the religious movement appropriated the old African ways of worshipping God in open spaces. Before the advent of missionaries in Africa, people used to worship their gods under certain trees, as well as in certain caves and mountains. Thus, Johane Masowe formed this black African movement to withdraw from all the white man's initiatives to resocialise and appropriate the traditional African way of reaching out to God (Machingura 2014:179). For Machingura, JMC movement is categorised as a sect because of its radical message of withdrawal from all European influences, the destruction of all religious books, including the Bible, and the shunning of all inventions by whites (Machingura 2014:179).
Congregating in open spaces is not the result of a lack of money (Mukonyora 2007) with regard to the Johane Masowe religious movement in Zimbabwe. A careful analysis of the church's occupancy of open spaces for the purpose of worship has revealed that JMC's occupancy of open spaces is theologically oriented. As stated by Musoni and Gundani (2019:17), the JMC congregating under sacred traditional African trees or near traditional African sacred shrines, such as pools, hills and mountains is a conscious decision. This is how open-space congregation becomes the trademark of all white garment churches in Zimbabwe (Mukonyora 2001:17).

Examples of traditional sacred shrines that are re-appropriated and re-socialised by the JMC as alluded to in Musoni's PhD thesis, 'Inculturated African spiritual elements of faith by the JMC yeNyenyedzi church in Zimbabwe', are the Chivavarira Hill and the Ngarikure Pool (Musoni 2017). These two sacred places, which are collectively known as the Gonawapotera, are currently the most sacred shrines of the traditional Chirumhanzu community (Zvarevashe 1978:10; Musoni 2017) Thus, this article postulates that the JMC was categorised as a sect and not a Christian church because of its decisive preference of reclaiming such existing traditional African shrines for its religious gatherings and rituals. These shrines are always apart from the church buildings of colonialists and located in bushy areas. However, the claim underlying the occupation of such places is that a deeper spiritual connection can be achieved in unpolluted and uninhabited places than in missionary temples (Mlambo \& Mukahlera 2014:89). Therefore, the question raised is: can the JMC be labelled a sect because of the shunning of buildings in preference for African traditional shrines for religious gatherings and rituals?

This study has a strong view that this practice of re-socialising and appropriating the mother religion's sacred shrines by breakaway religious movements is not uniquely JMC. The author argues in this research study that Christianity, as an off-shoot of Judaism, continued to use the temple and synagogue for worship. Christianity began as a Jewish sect in the mid-first century originating in the Levant region of the Middle East (modern Israel and Palestine), before it spread quickly to Syria, Mesopotamia, Asia Minor, Egypt and other parts of the world. Thus, Christians of that time did not abandon temple gatherings. The only difference was the amount of time they occupied the temple. Thus, the author argues that temple gatherings by the early church was a continuation of the sacrality of the Jewish temple. Like the early church, the members of the JMC religious movement posit that Mwari, who is the final authority behind a person's success, is found in the already traditional African shrines such as the Chivavarira Hill and the Ndarikure Pool, and hence, there is appropriation of these spaces. In an interview, one elder member of the JMC in support of the above assertion had the following to say:

'Ndarikure and Chivavarira are sacred places. It is not a surprise, we are here for spiritual nourishment. The Spirit told our spiritual fathers to come and occupy this place in 2000. 
From 2000 up to this day, every year, during our annual prayer muteuro wegore) we come here for deeper spirituality. I have been coming to this place for deliverance and I am among the several people who have been helped by attending muteuro wegore at this place.' (Interview: Participant 1, 79 years, Male, Masowe member 26/10/2020)

Thus, whilst other scholars regarded the withdrawing of the JMC from temple gatherings as a feature that characterised a sect, it was argued in this study that the JMC as a religious movement has maintained the centrality of traditional sacred shrines from where it emerged. Another issue that has heightened the debate regarding the Christian church-sect dichotomy is found in the analysis of the JMC spirituality regarding the messianic tendencies.

\section{Messianic tendencies}

The second argument raised by critics of the movement is that the JMC falls outside the category of a church to a sect because of the religious movement's denigration of the messiahship of Jesus for black Africans. For this religious movement, Jesus who was regarded as white in his physical self was sent by God to the white communities overseas (mhiri yegungwa) (Musoni \& Gundani 2016:5). Perhaps, the allegation that Jesus was white and was sent to white communities is based on the images of a white Jesus portrayed by missionaries in Africa. Indeed, Jesus was portrayed by missionaries as a white man with a long beard wearing a white robe. Thus, the JMC members argued that God would not have sent white Jesus to save black communities:
'At first God sent his Angel Christ [mutumwaChristo] into Jesus the son of Joseph [a white man] of the overseas as we grow-up knowing. This Jesus was an ordinary son of Mary and Joseph. Jesus became the white community angel (mutumwa) when the Angel Christ came upon him. Thus, his name changed to Christo. However, because people of the overseas did want to get out of their evil deeds they killed him. After his death, Jesus was buried but the Angel Christ went back to God. God the father was unhappy and sworn by himself that he will never again send his Angel to the white communities. Thus, the same Angel which worked in Jesus came down to the black community but with a new name Johane. This Angel Johane came and find Shonhiwa Masedza. After Shonhiwa died, the Angel Johane went back to the father and came back with a new name Emanuweri. The Angel Emanuweri came and find Mudyiwa dzangara, thus how Mudyiwa's name was changed to Emanuweri. And after Mudyiwa died the Angel Emanuweri went back to God and came back with a new name Nyenyedzi. Angel Nyenyedzi came and find Sandros Nhamoyebonde.' (Interview: Participant 2, 60 years, Female, Masowe member 19/06/2020)

The members of this religious movement argue that the Angel of God (Christo) who worked through Jesus of the overseas came to Africa, but assumed different forms and shapes. Thus, the author argued in this research study that this theology of continuous incarnation in the JMC religious movement is what early scholars referred to as Messianic tendencies. The phrase Messianic tendencies was used to refer to religious leaders being worshipped as the Messiah or the saviour of the people. According to Dillon-Malone, Johane Masowe presented himself as the Messiah whom God had chosen for the African people (Dillon-Malone 1978:27). Dillon-Malone's argument amongst other scholars seems to be substantiated by what one of the JMC members revealed during an interview:

'We are the disciples of Johane Masowe. Jesus was sent by God not to Africa but to the overseas nations/mhiri yegungwa. God sent Mutumwa Johane, Emanuweri and Nyenyedzi to African communities. That is the reason why we are called the apostles of Johane. Jesus had his own disciples, too overseas. Because of that reason we prefer to be called the disciples of Johane. We do not have Christians in Africa because Christians were the disciples of Jesu Christo, and Jesu Christo never came to Africa. Also, during Jesus' lifetime, there were no Christians but only the apostles of Jesus. After Jesus was killed, then the apostles were called Christians because they behaved like Jesus Christ. Likewise, we are called vadzidzi va Johane because we follow Johane's teachings.' (Interview: Participant 3, 70 years, Male, Masowe member 26/10/2020)

As claimed by Dillon-Malone, the intention of the JMC religious movements has been to create a body of material around the person of its founder for blacks, which corresponds to the body of material that has emerged around Jesus Christ for whites (Dillon-Malone 1978:51). It is against this background that some scholars argue that because the salvific work of Jesus was replaced by the work of the messianic figure of Johane Masowe, the JMC has become a sect and not a Christian Church. However, categorising the JMC as a sect based on the above allegation seems to be problematic. The reason for this submission is that for this Zimbabwean religious movement, God sent a black messianic figure to black communities in the same way he sent a white messianic figure to white communities. Thus, the denial of Jesus in terms of his physical self by the JMC churches does not translate into the denial of Christ in this African religious movement. We observed that the JMC acknowledges that after Jesus had been crucified by the enemies of the gospel, the Angel (Spirit) Christ went back to God, and that God later sent the same angel to Africa. This angel first entered Shonhiwa Masedza and was renamed Johane, then the angel entered Mudyiwa Dzangare whose name was changed to Emanuweri, and finally, the angel entered Sandros Nhamoyebonde and he was named Nyenyedzi as discussed earlier (interview, 23/07/2020). This is what this article was referring to as the propagation of a theology of continuous incarnation within the JMC religious movement in Zimbabwe. According to this movement, the angel of God has assumed different images in different people of different nationalities (Musoni 2018).

\section{The denigration of the written scripture for theology}

The JMC religious movement has set itself apart from other Christian churches in many ways. Whilst other Zimbabwe African indigenous and missionary churches acknowledge the Bible as the source of theology and spirituality, the JMC 
approaches it differently. For the JMC, the Bible was the 'insignia of colonialism' (Engelke 2005:787). Thus, the role of the Bible became a point of disagreement between the Johane Masowe and Johane Marange religious movements in Zimbabwe (Engelke 2005:786). According to Engelke, some members who had joined the Johane Masowe were disappointed when they realised that the movement regarded the Bible as irrelevant; consequently, they parted to join Johane Marange (Engelke 2005:789). This parting gave rise to the distinction between Friday and Saturday White garment churches in Zimbabwe (Engelke 2005:787). Thus, Johane Masowe was clear regarding the point that the Bible has no place in his new religious movement and must be burnt (Dillon-Malone 1978). Accordingly, Johane Masowe rejected the Bible as a way of transmitting the Word of God. For Johane, the prophet is the transmitter of the Word. This happens 'live and directly' by being possessed by the spirit (Engelke 2007:507). This is what is referred to as tsanangudzo dzemweya. Tsanangudzo dzemweya is the fresh and contemporary utterances of the Spirit by a prophet to address imminent and current problems. Accordingly, within the $\mathrm{JMC}$, the Bible is regarded as a book that comprises of stories about other people, and they are not relevant to African people (Engelke 2007:508).

Besides the utterances of the Spirit (tsanangudzo dzemweya) during their Friday prayers, members of this religious movement are reminded of the three-doctrinal teachings of Johane, Emanuweri and Nyenyedzi, which are commonly referred to as tsoro yaJohane or tsoro yamutatu [the spiritual journey of Johane, Emanuweri and Nyenyedzi] (Musoni \& Gundani 2016:13). The author argues in this research study that the spiritual experiences of Johane Masowe, Emanuweri and Nyenyedzi have remained authoritative and cannot be questioned by the followers of the JMC religious movement. Based on this understanding, members of the JMC movement believe that Johane, Emanuweri and Nyenyedzi received the complete revelation needed by this religious movement from God through the Holy Spirit, and hence, they condemn the reading of the Bible during religious services. All this put together - the tsanangudzo dzemweya, Gumi remitemo and tsoro Johane - constitutes the full charter of this religious movement (Anderson 2001:116).

When the JMC members were questioned about the fact that whilst they claim to be a religious movement without reading or using the Bible (Engelke 2007:55), even though every member could still recite the biblical Mosaic laws, the response given was the following:

'The Holy Spirit who was there to inspire the writing of the Bible is the same Spirit who gave the Ten commandments to Baba (father) Johane. The history tells us that while Baba Johane was praying in a hill Marimba in the city of Harare, the Spirit gave him the Ten commandment. These ten commandments became our first scripture then followed by visions and dreams. We don't read or use the Bible because the Bible is foreign to us as Africans. But we don't say the Bible is bad no ... The issue is we believe in the continuous revelation. If people rely on the Bible which was written 2000 years ago, how will you address the human existential problems like Covid-19. Right now, as I speak with you, our prophet was told about the coming of Covid way back in 2017 during prayer, that a fever was coming from the sea, people will say its flu but is not flu.' (Interview: Participant 5, 55 years, Female, Masowe member 03/05/2020)

Again, critics of this movement posit that selection of the Mosaic laws only and regarding the entire Bible as irrelevant for the Johane Masowe Church spirituality is typical of a sect (Bishau 2010:78). However, a strict phenomenological approach would argue that dismissing a religious movement for selecting the Mosaic laws only as the movement disregards other parts of the Bible as a sectarian tendency is an unfair judgement. From a phenomenological perspective, there is no church that uses the whole Bible, but every Christian church uses the Bible selectively. This is the reason why we have different Christian denominations today such as the Roman Catholics, Anglicans, Pentecostals, Jehovah's witness and the Seventh day Adventists. In addition, to indicate the problematic nature of this criterion, no rules have been developed regarding the biblical interpretation (hermeneutics) and '[o]n top of which mountain would one judge other religions' (Chitando et al. 2014:5).

\section{Conclusion}

The problem of classifying the JMC religious movement as a sect was highlighted in this article. Firstly, a common theoretical framework was proposed for distinguishing a Christian church from a sect. The researcher noted that for some scholars, for a movement to be classified as a Christian church, it must uphold the most generally agreed-upon spiritual elements of faith. The three central spiritual elements that have distinguished a Christian church from a sect discussed included the congregation in temples, the reading of the scripture (the Bible) during services and the acceptance of Jesus Christ as the mediator between the living and God. Accordingly, this study argued that in the process of redefining its theology and spirituality, the JMC abandoned temple gatherings in favour of open spaces, an African traditional way of approaching the divine. Furthermore, the JMC propagated a theology of continuous incarnation and concluded that Jesus who became Christo was sent by God to the white communities, whilst the same Spirit (Christo) incarnated in Shonhiwa and was renamed Johane, in Mudyiwa who was named Emanuweri, and finally, in Sandros who was named Nyenyedzi, respectively, to mediate between black Africans and God. The reason for this continuous incarnation according to the JMC is for the purpose of saving different nationalities as they will associate themselves with the Messiah of their colour and creed. The JMC argues that God would not have sent a white Messiah to a black community. This study has also revealed that the JMC has selected the 10 Commandments in the Bible and regards other parts of the Bible as irrelevant for Africans. In addition to the 10 Commandments, the JMC believe in the fresh utterances of the Spirit against reading the old pages of the Bible. In this sense, this Zimbabwean movement propagates a theology of continuous divine revelation. Therefore, it is 
against these differences, the JMC religious movement was labelled a sect by the critics of the movement.

This study, however, concluded by arguing that to disqualify a religious movement from being a Christian movement simply because it does not have a temple does not derive its theology from the whole Bible and propagating the theology of the continuous incarnation of Christo is extremely problematic. The reason for this submission is that what is being displayed here is just the religious language problem. The JMC believe in the continuous revelation and is not limited to the written scripture, and also focus on the present manifestation of the Holy Spirit. The religious movement upholds the theory of continuous incarnation where the Messiah continued to assume different images and, finally, the movement believes in the appropriation of traditional sacred shrines with the knowledge that a sacred shrine continues to be sacred for all generations. Thus, the description of the JMC churches as sects is tenuous, at best, or at the worst, represents theological arrogance on the part of the scholars who do not appreciate African religious creativity and innovation.

Having analysed the different criteria used to categorise the JMC as a sect and not as a church, therefore, this study underscores the highly problematic nature of imposing western or foreign categories on African religious phenomena. Although at face value it would appear that the JMC religious movement has stepped out of the Christian playing field according to Holt (2005), a closer analysis shows that it is extremely difficult for any scholar to map out the precise boundaries of Christianity. It may be more helpful to approach African religious phenomena such as the JMC, from the perspective of originality and creativity than from western epistemologies and from the religious othering others not gathering of others. These are African religious movements that are seeking to translate the Christian message into African categories in the face of racism, exclusion and denial of African spirituality.

\section{Acknowledgements}

The author wishes to thank prof Andries van Aarde, the editors of HTS, the anonymous peer reviewers and the AOSIS team for their invaluable work and suggestions.

\section{Competing interests}

The author has declared that no competing interests exist.

\section{Author's contribution}

I declare that I am the sole author of this research article.

\section{Ethical considerations}

This article followed all ethical standards for carrying out research without direct contact with human or animal subjects.

\section{Funding information}

This research received no specific grant from any funding agency in the public, commercial or not-for-profit sectors.

\section{Data availability}

Data sharing is not applicable to this research article as no new data were created or analysed in this study.

\section{Disclaimer}

The views and opinions expressed in this research article are those of the author and do not necessarily reflect the official policy or position of any affiliated agency of the author.

\section{References}

Adogame, A., 2013, The African Christian diaspora: New currents and emerging trends in world Christianity, Bloomsbury, New York, NY.

Anderson, A., 2001, African reformation: African initiated Christianity in the 20th century, Africa World Press, Trenton, NJ.

Barrett, D., 1968, Schism and renewal in Africa, Oxford University Press, London.

Bishau, D., 2010, Reign with him for thousand years (Rve20:6): A socio-hermeneutical exposition of biblical and contemporary millennium movements in Zimbabwe as radical responses to deprivation, University of Bamberg Press, Bamberg.

Burridge, R., 2001, 'Jesus and the origins of Christian spirituality', in G. Murshell (ed.), The story of Christian spirituality: Two thousand years from east to west, pp. 11-30, Lion Publishing, Oxford.

Chitando, E., 2004, 'African instituted churches in Southern Africa: Paragons of regional integration', African Journal of International Affairs 7(1-2), 117-132. https://doi.org/10.4314/ajia.v7i1-2.57226

Chitando, E., Mapuranga, T.P. \& Taringa, N.T., 2014, 'On top of which mountain does one stand to judge religion? Debates from a Zimbabwean context', Journal for the Study of Religion 27(2), 115-136.

Cox, J.L., 1992, Expressing the sacred: An introduction to the phenomenology of religion, University of Zimbabwe, Harare.

Daneel, M.L., 1973, 'The Christian gospel and the ancestor cult', Missionalia 1(2), 46-73.

Daneel, M.L., 1987, Quest for belonging: Introduction to a study of African independent churches, Mambo Press, Gweru.

Denzin, N.K. \& Lincoln, Y.S. (eds.), 2011, The Sage handbook of qualitative research, Sage, Los Angeles, CA.

Dillon-Malone, C.M., 1978, The Korsten basketmakers: A study of the Masowe apostles: An indigenous African religious movement, Manchester University Press, Manchester.

Dube, N., Nkomo, T.S. \& Khosa, P., 2017, 'Condom usage negotiation among customarily married women in Katlehong, Johannesburg', Sage 7(1), 1-7. https:// doi.org/10.1177/2158244016687345

Engelke, M., 2005, 'The early days of Johane Masowe: Self-doubt, uncertainty, and religious transformation', Journal for the Study of Religion 47(4), 781-808. https:// doi.org/10.1017/S0010417505000356

Engelke, M., 2007, A problem of presence: Beyond scripture in an African church, University of California Press, Los Angeles, CA.

Gunda, R.M., 2014, 'African "Biblical" Christianity: Understanding the "spirit-type" African initiated churches in Zimbabwe', in E. Kugler, J. Chitando \& R.M. Gunda (eds.), Multiplying in the spirit African initiated churches in Zimbabwe, 15th edn., pp. 145-160, University of Bamberg, Bamberg.

Guri, W., 2017, 'ZANU (PF) captures the church', in The Zimbabwean: A voice of the voiceless, viewed 11 March 2020, from https://www.thezimbabwean.co/2017/11/ zanu-pf-captures-church/.

Guri, W., 2018, 1: The founding of African independent churches 3, Why so many new churches, June.

Hastings, A., 1996, The church in Africa 1450-1950, Clarendon Press, Oxford.

Holt, P., 2005, Thirsty for God: A brief history of Christian spirituality, Augsburg Firtress Press, New York, NY.

Johnson, B., 1971, 'Church and Sect Revisited', Journal for the Scientific Study of Religion, 10(2), 124-137.

Kealotswe, O., 2014, 'The nature and character of the African independent churches (AICs) in the 21st century: Their theological and social agenda', Studia Historiae Ecclesiasticae 40(2), 227-242, viewed 10 March 2019, from http://www.scielo. org.za/pdf/she/v40n2/15.pdf.

Keke, E.C., 2010, 'Phenomenological approach to the study of religion: A historical perspective', European Journal of Scientific Research 44(2), 266-274.

Machingura, F., 2014, 'Martyring of people over radical beliefs: A critical look at the Johane Marange Apostolic Church's perception of education and health (Family planning methods)', in E. Chitando, R.M. Gunda \& J. Kugler (eds.), Multiplying in the spirit: African initiated churches in Zimbabwe, pp. 175-198, University of Bamberg Press, Bamberg.

Mackay, D. \& Motsi, P., 1988, 'Some contemporary trends in independent churches in Zimbabwe: The case of ZCC and Johane Marange's vapositori', in C.F. Hallencreutz \& A. Moyo (eds.), Church and state in Zimbabwe, pp. 107-121, Mambo Press, Gweru. 
Mbiti, J.S., 1986, Bible and theology in African Christianity, Oxford University Press, Nairobi.

Mlambo, O.B. \& Mukahlera, T.R., 2014, 'Tradition in African initiated churches: Analogies with pre-Christian Greek religion', in J. Kugler, E. Chitando \& R.M. Gunda (eds.), Multiplying in the Spirit: African initiated churches in Zimbabwe, 15th edn. pp. 79-91, University of Bamberg Press, Bamberg.

Mukonyora, I., 2007, Wandering a gendered wilderness: Suffering \& healing in an African initiated church, P. Lang, New York, NY.

Mushete, N., 1978, 'Unity of faith and pluralism in theology', in T. Sergio \& F. Virginia (eds.), The emergent gospel: Theology from the development world, pp. 55-78, Orbis Books, Mary knoll, New York, NY.

Musoni, P., 2017, 'Inculturated African spiritual elements in Johane Masowe Chishanu YeNyenyedzi Church in Zimbabwe', University of Pretoria, Pretoria, viewed 22 March 2020, from https://repository.up.ac.za/bitstream/handle/2263/61196/ Musoni Inculturated 2017. pdf?sequence=1\&isAllowed=y.

Musoni, P., 2018, 'Re-visiting Christology from an indigenous perspective: A study of the new images of Jesus in African Christianity in the Zimbabwean context', in Z. Dube, L. Maseno \& E.S. Mligo (eds.), The Bible and sociological contours: Some African perspectives, pp. 31-44, Peter Lang, New York, NY.
Musoni, P. \& Gundani, P., 2016, 'Easter celebrations with a difference: A critical study of the Johane Masowe Chishanu YeNyenyedzi approach to the event', Studia Historiae Ecclesiasticae 42(1), 1-14. https://doi.org/10.17159/2412-4265/2016/422

Musoni, P. \& Gundani, P.H., 2019, 'Open space worship: A religious identity of the Johane Masowe Chishanu Church in Zimbabwe', Journal for the Study of Religion 32(2), 1-13. https://doi.org/10.17159/2413-3027/2019/v32n2a4

Oosthuizen, G.C., 1968, Post-Christianity in Africa, Wm. B. Eerdmans, Grand Rapids, MI.

Sibanda, F., 2017, 'Female leaders in the Midzimu Unoera sect in Guruve, Zimbabwe', in T.I. Bardsen, \& C. Giudice (eds.), Female leaders in new religious movements, pp. 209-228, Springer, Cham.

Sundkler, B., 1961, Bantu prophets in South Africa, Oxford University Press, London. Sundkler, B., 1991, 'African independent churches and their political roles', in C.F. Hallencreutz \& M. Palmberg (eds.), Religion and politics in Souther
pp. 123-138, The Scandinavian Institute of African Studies, Uppsala.

Turner, H.W., 1967, History of an African independent church, G K Hall, Boston, MA.

Viera, P.A., 2007, 'Christian missions in Africa and their role in the transformation of African societies', Asian and African Studies Jerusalem), viewed 20 July 2019, from https://www.sav.sk/journals/uploads/102313498Vilhanová.pdf.

Zvarevashe, I., 1978, Gonawapotera, College Press, Harare. 